\title{
Defining the Nation and Confining the Musician: The Case of Irish Traditional Music
}

\section{HELEN O'SHEA}

When a Swedish company performs The Magic Flute, or a children's orchestra from Venezuela plays a Vivaldi concerto, or a Japanese soprano sings Schubert, audiences pay little attention to the correspondence or otherwise between the performer's nationality and that of the composer, even when the music they play is linked to nationality, as in versions of German Volkslieder. When a French musician plays the kora or a Swede sings rai, however, these performances are more likely to be evaluated in terms of the musicians' nationality or ethnicity. In world music scenes, in particular, authenticity is defined as much by the ethnicity and nationality of the performers as it is by the faithfulness of their performance to earlier models and masters.

These comparisons from the differing scenes of art music and world music provide a starting point for challenging assumptions that music "of the people," whether it is performed by tradition bearers, world music enthusiasts, or Western art musicians, inevitably expresses the collective character of that people.

In what follows I use a well-known song to exemplify the processes by which meanings become attached to musical texts. I hope to demonstrate that such meanings do not inhere in the musical texts themselves but in the discourses within which they are retrieved, revised, performed, and received, as well as in the literary texts (lyrics) with which they are linked. Using the case of Irish traditional music, I demonstrate some of the ways in which musical texts may acquire an affective language and a gendered discourse based on colonial stereotypes, and how the values embedded in these discourses may be inverted within anti-colonial movements. I then argue that this discursive construction of a national musical tradition has had the effect of limiting or devaluing the participation of certain groups within the nation, particularly women.

\section{A "beautiful air" from County Derry}

In exploring the genealogy of the musical text now best known as the song "Danny Boy," we can follow the air from the Irish countryside to its urban centres and the imperial hub of London and back again, and as it is performed by street musicians, Irish nationalists, homesick emigrants, and by a wider public as an expression of loss and longing. In the process, this musical text exhibits some of the many ways in which musical meanings mutate across time and space, illustrating Edward Said's proposition that musical practice may be "contrapuntal": that it may embody and enact both imperial power and resistance to it. ${ }^{1}$

\footnotetext{
${ }^{1}$ Edward Said, Culture and Imperialism (London: Chatto \& Windus, 1993), 68.
} 
Underpinning Said's critical work is the concept of the worldliness of literary texts, which, he claims, "even in their most rarefied form are always enmeshed in circumstance, time, place, and society." A cultural text is not a representation of the material world but is an act located in that world and implicated in both the power relations within which it was produced, and in those within which it is consumed. A text's worldliness, then, is its situatedness in time and in social and political circumstances.

Musical texts exhibit this worldliness, but because music is non-denotative, in the sense that sounds in music depend upon the signifying processes of language in order to take on meaning, music is more open than literature, for example, to be interpreted in varying and even contradictory ways. This potentiality allows musical elements to accumulate delineated meanings, which are the product of images, associations and beliefs that inhere, not in the musical elements themselves, but in their social relations, their worldliness. ${ }^{3}$ When deeply embedded in cultural history, these delineated meanings sound "natural," as when we hear a minor third interval as "sad" and a major third as "happy." On the other hand, and because there is in fact no inherent relationship between a musical element and its delineated meaning, music also has the "nomadic" or "transgressive" ability to cross over into other domains, "to attach itself to, and become a part of, social formations, to vary its articulations and rhetoric depending on the occasion as well as the audience, plus the power and the gender situations in which it takes place."

"Danny Boy" is one of Ireland's best-loved songs and is often performed today as an emblem of Irishness. In Ulster, the song is as much a touchstone of identity among Catholics and republicans-who may sing additional verses about a pike-bearing rebel dying to set Ireland free-as it is among Protestants and loyalists-who are more likely to refer to it as the "Londonderry Air," a name it acquired in the late nineteenth century. This reminder that Derry was granted to London guilds at the beginning of the seventeenth century and the start of the major English colonization of Ulster is not the only way in which the song has been subsumed into the imperial culture. The air found its way into the realm of literate musicians through its publication in 1855 by the Irish antiquarian George Petrie (1790-1866), who had received a transcription of this "beautiful air" from a keen collector, Jane Ross, in a small County Derry town. ${ }^{5}$

The practice of transcribing, publishing, and recreating in performance musical texts from the Irish countryside was one part of the cultural movement that exhorted nationalists in Ireland (as did similar movements elsewhere in Europe) to hunt down, preserve and disseminate the indigenous culture. By the time Petrie's Collection of the Ancient Music of Ireland was published in 1855, this task was seen as urgent, since Ireland's "ancient" culture was then perceived to be in its death throes. In part, this crisis was attributed to the corrupting influences of the English language and urbanization. More immediately threatening to the continuity of musical practice in rural Ireland, however, was the annihilation of large parts of the rural population during the Great Famine of the 1840s. Among the most vulnerable to this devastation of lives and livelihoods were the poorest, itinerant workers, who had played a significant role in the oral transmission of musical texts over time and their distribution within Ireland and between

\footnotetext{
${ }^{2}$ Edward Said, The World, the Text and the Critic (Cambridge, MA: Harvard University Press, 1983), 35. The concept of music as a kind of universal language has been widely discredited. See, for example, Richard Leppert and Susan McClary, eds., Music and Society: The Politics of Composition, Performance and Reception (Cambridge: Cambridge University Press, 1987) and John Shepherd and Peter Wicke, Music and Cultural Theory (Cambridge: Polity Press, 1997).

${ }^{3}$ See Lucy Green, Music on Deaf Ears: Musical Meaning, Ideology, Education (Manchester and New York: Manchester University Press, 1988), 28.

${ }^{4}$ Edward Said, Musical Elaborations (New York: Columbia University Press, 1991), 70.

${ }^{5}$ George Petrie, The Petrie Collection of the Ancient Music of Ireland (Dublin: M. H. Gill, 1855), 57.
} 
Ireland and Scotland, where migrant labourers had the opportunity to pass on or to pick up songs and tunes.
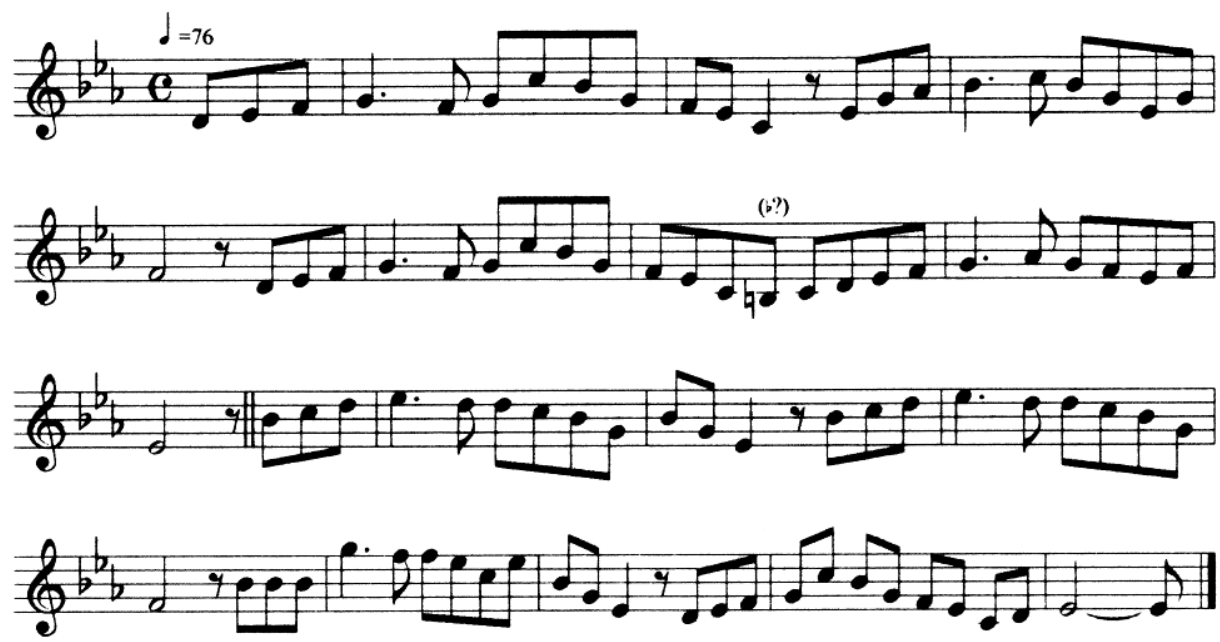

Figure 1. The unknown song that became "A Londonderry Air" and "Danny Boy." From David Cooper, ed., The Petrie Collection of the Ancient Music of Ireland (Cork: Cork University Press, 2002 [1855]), 94. Reproduced with kind permission of the author and Cork University Press.

Note that the transcription reproduced here is not an actual musical text, but the representation of a musical text: a description of a cultural act and not the act itself. Just as published collections of Ireland's Gaelic poetry were translated into English—since its intended readers, the English-speaking intelligentsia, were unfamiliar with the lingua franca-musical texts were "translated" into a form suited to the mainly urban, amateur musicians who performed them on piano and violin. These transcriptions were not used by those whose singing or instrumental playing they describe, for the popular musical tradition was an oral one.

In the province of Ulster, where this air was copied down, the project of cultural revival was at that time largely the work of Presbyterians. Jane Ross, who sent her transcription to George Petrie around 1851, was a descendant of Scottish planter John Rosse, who in 1609 had acquired land in County Derry confiscated from the O'Cahan family. An enthusiastic collector and preserver of "native" culture, Ross nevertheless stood outside that culture and her methods of transcribing were a product of her education in western art music on the pianoforte. It is highly unlikely, for example, that the source of her air, reputed to be an itinerant fiddle player, would have played in the key of E flat, in which she transcribed it (see Figure 1) when the more accommodating key of $D$ was available. The air in its prescriptive notation has also lost any embellishment or variation that may have distinguished the performance Ross heard. Its untempered tonality has been straitened by its adaptation for performance on the piano, its rhythm standardized. Perhaps the greatest difference between the tune as performed within the oral tradition and what Petrie's modern editor, David Cooper, calls the "rhythmic and tonal strait-jacket" of transcription is the result of 
Petrie's harmonic settings. ${ }^{6}$ These appealed to the educated, mainly urban and Anglo-Irish middle-class who bought collections of Irish tunes and performed them as patriotic drawing-room entertainment. Thus a cultural act performed anonymously in County Derry (Ross identified neither the musician nor the name of the tune) was transformed into a standardized written version and transmitted to a new social environment.

Some musicologists have expressed reservations about the accuracy of Jane Ross's transcription. Hugh Shields, for example, has attributed the tune's upward swoop, the downfall of many a bar-room warbler, to the "keyboard divagations of a middle-class lady." Anne Gilchrist accuses Ross of incompetently recording the metre as quadruple rather than the triple metre that was typical of Irish airs. ${ }^{8}$ Brian Audley takes a similar view when he links the Derry air with "The Young Man's Dream," an air in triple time that Edward Bunting (1773-1843), whose work in collecting and publishing Irish music from the oral tradition preceded Petrie's, had transcribed from the playing of the elderly harper Denis Hempson (or Hampsey) in the 1790s. In proposing that the "Londonderry Air" was simply a version of "The Young Man's Dream" that had been rhythmically misapprehended, Audley offers a solution to the mystery of Jane Ross's musical sources, for the tune in the form she transcribed it has not been recorded by any other collector. ${ }^{9}$

\section{Distinctly and lively.}

\section{" QISLIN] an OIJfIR." “'The Young Man's Dream."}

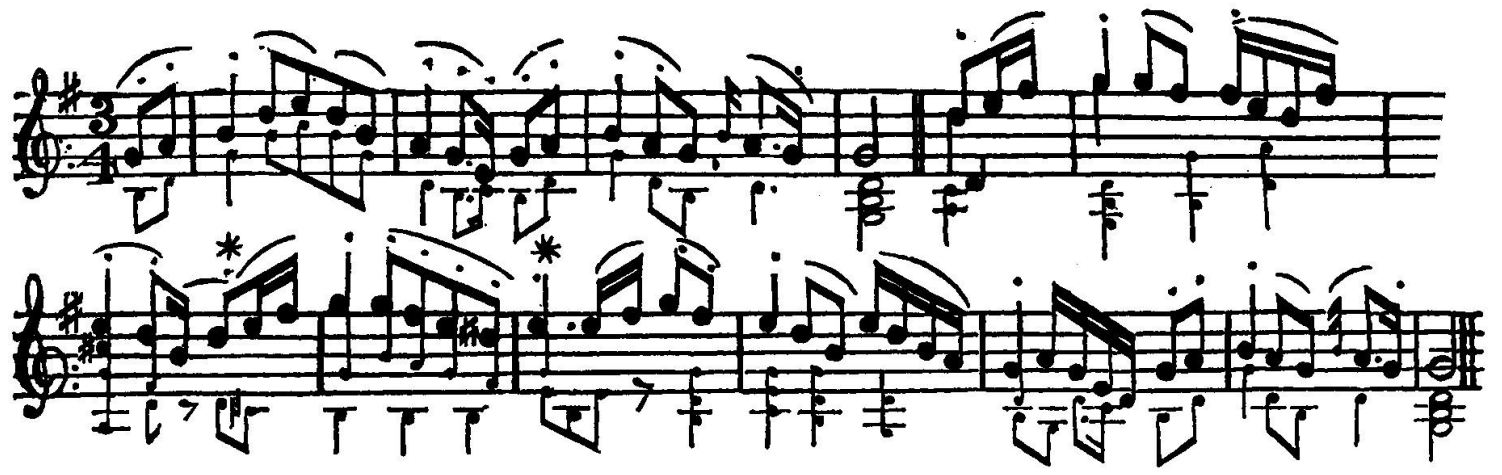

Figure 2. "Aisling an Oighfir" or "The Young Man's Dream," in Edward Bunting, A General Collection of the Ancient Music of Ireland (Dublin: W. Power, 1796), 9. From a facsimile edition, The Ancient Music of Ireland (Dublin: Waltons, 1969). Reproduced with kind permission of Dover Publications, Inc.

\footnotetext{
${ }^{6}$ David Cooper, "Editor's Introduction," The Petrie Collection of the Ancient Music of Ireland (Cork: Cork University Press, 2002), 19.

${ }^{7}$ Hugh Shields, "New Dates for Old Songs, 1766-1803," Long Room 18-19 (1979): 34-41.

${ }^{8}$ Anne Gilchrist, "A New Light upon the Londonderry Air,” Fournal of the English Folk Dance and Song Society 1, no. 3 (1934): $115-21$.

${ }^{9}$ Brian Audley, "The Provenance of the Londonderry Air," Fournal of the Royal Musical Association 125, no. 2 (2000): 205-47; 228.
} 
In the late eighteenth century, during a period of political uprisings and repression of the Catholic majority in Ireland, this close variant of the "Londonderry Air" conveyed verses in the form of the aisling or dream-vision poem. "Aisling an Oighfir," translated from the Gaelic as "The Young Man's Dream," belonged to an allegorical poetical form employing the figure of a beautiful woman who variously personifies Ireland or the Catholic underclass, and who resists masculine interference and cries out for justice or protection. Although the political allegory can be overshadowed by the titillation of a text enumerating womanly charms and the narrator's desire to be united with her (as is the case in "Aisling an Oighfir"), the form itself was closely associated with subversive anti-colonial and pro-Jacobite messages. ${ }^{11}$

"The Young Man's Dream" was also set to other verses as "Castle Hyde" by an itinerant balladeer for his ungenerous patron. That song was later parodied by Richard Alfred Millikin as "The Groves of Barley." It is significant that Thomas Moore later used the melody as the basis for two different songs, which were published in Moore's Irish Melodies between 1865 and 1889. One of those songs was "Tis the Last Rose of Summer," which he based on the "old air," "The Groves of Barley"; the other is the lesserknown "As a Beam o'er the Face of the Waters," for which he cites his source as "The Young Man's Dream." Both songs retain the triple metre of the source tune, and in both cases internal metrical differences in the tune correspond with metrical differences in the lyrics, pointing to another way in which song airs mutate over time. Similarly, the languid, emotive accompaniments Moore provides completely alter the character of the earlier Irish ballads.

Audley points out melodic similarities (and metrical differences) between the "Londonderry Air" and another contemporaneous song, "Devorgilla's Lament," which adopts the popular confessional form, beginning "Oh shrive me, Father . . ." Audley thus exposes the opportunistic variation of metre in the interests of conveying lyrics and the complex connections among contemporaneous musical texts: Irishlanguage poetry with anti-colonial connections, English verses that provide a critique of the landed gentry's patronage of itinerant musicians, as well as doggerel in Irish (another variant of the air conveys the drinking song "Preab an Ól” or "Spring into the Drink"). ${ }^{12}$

But then if we were to go further back, searching, as Bruce Olson has done, among the manuscripts in the Scots Musical Museum and in collections of broadside ballads, we may find similar versions of "The Young Man's Dream" had been transcribed in Scotland and in England as early as the seventeenth century. ${ }^{13}$ As we search among the tune's variants, we find, not the musical texts of a "pure" indigenous culture (as Irish cultural nationalists believed), but a vigorous hybridity. We can see, too, that the many variants of this melody conveyed happy, grieving, mischievous, subversive or rollicking verses. In its diverse musical and literary manifestations, the air we know today as "Danny Boy" thus exhibits the hybrid richness of life in Ireland two hundred years ago.

Moving forward in time from the publication of "Londonderry Air" in 1855, and as the market for printed music expanded in the second half of the nineteenth century, many versifiers, particularly in England, published new lyrics to the by then widely enjoyed melody with recurrent themes of love, loss and dying. With its musical energies bowdlerized, its varying sound standardized, translocated from the

\footnotetext{
${ }^{10}$ A basic midi version of "The Young Man's Dream" may be heard at <www.standingstones.com/midi/aislean.mid >, in which the melodic similarities to "Danny Boy" are evident, despite the metrical difference.

${ }^{11}$ See Máirín Nic Eoin, "Aisling," in The Encyclopaedia of Ireland, ed. Brian Lalor (Dublin: Gill \& Macmillan, 2003 ), 17.

12 Petrie, 228.

${ }^{13}$ Bruce Olson's discoveries are recorded in Michael Robinson, "Danny Boy-The Mystery Returns!, or, The Young Man's Dream," which can be accessed at <www.standingstones.com/aisling/html $>$.
} 
rural poor to the urban middle class, the air came to be regarded as the quintessential Irish song. Most other lyrics were forgotten once "Danny Boy," the work of Frederick Weatherly, a London barrister and prolific songwriter, captured public sentiment when it was published in 1913. Among Irish emigrant populations and their descendants, it became a vehicle for conveying the grief of exile and its recuperation in nostalgia. ${ }^{14}$ There are now thousands of recordings of "Danny Boy" by musicians in musical genres including light classical, jazz, rock, punk, country, and "Celtic." All are melancholy to the point where not only the song, but the mood it conveys, have come to represent the Irish character and condition. The air has been used, with various lyrics, at the most elevated of public expressions of grief, at the funerals of President John Kennedy (1963), Elvis Presley (1977) and Princess Diana (1997).

Ireland's best-loved song, paradigm of melancholy Irishness, has merely acquired this delineation in the process of moving into imperial culture. Before I turn to the circumstances in which this musical stereotype came about, however, I shall introduce one more version of the "Londonderry Air." The accretion of musical associations between a melancholy sentiment and Irishness is evident in the air's incorporation into "British folksong" as a musical emblem of Ireland. This is demonstrated particularly well by the UK Theme, which was played on BBC Radio 4 every morning between 1973 and 2006 to mark the transition from its World Service to domestic programs. ${ }^{15}$

This five-minute fantasia, described as a "national medley," constructs a musical version of a United Kingdom of Britain and Ireland. The English folk song "Early One Morning" introduces the main theme, the march-time "Rule Britannia," complete with military brass and drum rolls. The plaintive "Londonderry Air" follows on English horn and harp (the emblematic instruments of England and Ireland respectively) and is interwoven with a wistful string version of the Scottish song "Annie Laurie." The Royal Navy arrives with the "Drunken Sailor," links arms with England's "Greensleeves," and is followed by the Welsh "Men of Harlech" combined with "Scotland the Brave" (musical emblems of the British Army's Welsh and Scottish regiments). The triumphant climax of "Rule Britannia" is heralded by a reprise of "Early One Morning" with an overlay of Purcell's "Trumpet Voluntary" to emphasize the dominant Englishness of this musically United Kingdom: Britannia rules by incorporating the Celtic components of that kingdom.

Composed by Fritz Spiegl (1926-2003), a refugee from Hitler's Anschluss, the UK Theme draws upon delineated musical meanings, eliding the political implications of the piece, for Britannia's musical triumph is a product of the assimilation of cultural difference. The romance of Celtic sentiment softens the militaristic might of the Anglo-Saxon, but in the process the Celtic theme is absorbed. We hear the wistful Irish melody and recognise in it the racial stereotype of the Celt. The feminine sadness of strings is drawn into the embrace of imperial brass. They harmonize. There is climax. In adding to the British whole, the "Londonderry Air" loses its Celtic identity: a metonym for the processes by which (it is implied) empires justly absorb colonies and are the better for doing so. Their appreciation and assimilation of exotic qualities adds to the alleged humanity of colonial power, while the colonized Celts' differentiated

\footnotetext{
${ }^{14}$ For example, the recording of John McCormack's “Oh Mary Dear," from fohn McCormack: Legendary Irish Tenor (1935; Goldies, 2001), which can be accessed at: < http://www.cdworld.ie/mp3/10953_000100010016.mp3>. Although a hugely popular recording, the lyrics McCormack used did not take hold.

${ }^{15}$ Although the five-minute $U K$ Theme was replaced by a much shorter piece in 2006, the original can still be heard via the BBC 4 website, <www.bbc.co.uk/radio4/history/uk_theme.html>.

${ }^{16}$ See cover of CD, The BBC Radio 4 UK Theme, performed by the Royal Ballet Sinfonia with Gavin Sutherland (St Helens, UK: Sweetspot Music, 2006).
} 
identity is diluted through cultural contact. The very thing that makes the empire rich makes its colonial subjects poor.

\section{The gendered discourses of Irish nationalism and English colonialism}

The fact that an orchestral setting of a tune assumed to be of Irish provenance evokes a familiar stereotype - the feminine, melancholy, artistic, charming but impractical Celt-begs two rather different questions. First, why these particular characteristics? Second, how might this stereotype relate to its masculine countertype, the brutish buffoon epitomized by the "Stage Irishman"? I will attempt to answer each of these questions in turn.

At the end of the eighteenth century, Protestants in Ireland became increasingly alienated by colonial economic and political policies, particularly after the failed 1798 Rebellion, when the Act of Union of 1800 abolished the Irish parliament and returned political power to England. In a population with deep economic, class, religious, ethnic, cultural, and geographical divisions, cultural nationalists sought political unity by promoting cultural unity. In this and subsequent mainly Protestant cultural nationalist movements in the course of the nineteenth century, Irish literary and musical texts were recovered, translated and disseminated as representative of what was presumed to be a continuous, ancient, and exclusively Irish culture. As in other European proto-nations, the leading cultural nationalists were urban intellectuals influenced by liberation movements elsewhere, by unease about urbanization and industrialization, and by philosophical writings, notably those of Johann Herder, who promoted the view that European civilization comprised separate "peoples" whose language and culture (thought to be transmitted unchanged since ancient times by the rural "folk") were congruent with a national territory.

Irish cultural nationalists differed from their European counterparts in seeking aristocratic rather than popular musical texts. As historian John Hutchinson points out, the goals of Gaelic revival were "to reconcile the different traditions of Ireland and guide a reunited Irish people into a golden future via a return to the exemplars of the ancient past." ${ }^{17}$ Thus the texts recovered and published from around 1800 by collectors, most prominently Edward Bunting, included the surviving repertoire of harpers whose antecedents had been the bards of the pre-colonial Gaelic aristocracy, as well as the airs of songs regarded as "ancient," an epithet that appeared frequently in published collections, despite the fact that they included songs and tunes that were much more recently composed or had arrived from Scotland or England. Thus, in introducing his setting of the "beautiful air" Jane Ross transcribed from an unknown musician, and which he agrees must be "very old," George Petrie remarks on "the old Irish race," which "still forms the great majority of [County Derry's] peasant inhabitants; and there are few, if any, counties in which ... the ancient melodies of the country have been so extensively preserved." 18 By seeking music associated with a period pre-dating the English invasions of Ireland, cultural nationalists were able more convincingly to promote the idea of cultural unity and political reconciliation within Ireland's diverse population. By focusing their efforts on music associated with the former Gaelic aristocracy, they also constructed a body of musical texts that reflected their own ambitions to become political leaders of a united Ireland, rather than promoting a "people's music" that might align with a popular anti-colonial movement, as happened elsewhere.

\footnotetext{
${ }^{17}$ John Hutchinson, The Dynamics of Cultural Nationalism: The Gaelic Revival and the Creation of the Irish Nation State (London: Allen \& Unwin, 1987), 56.

${ }^{18}$ Petrie, 57.
} 


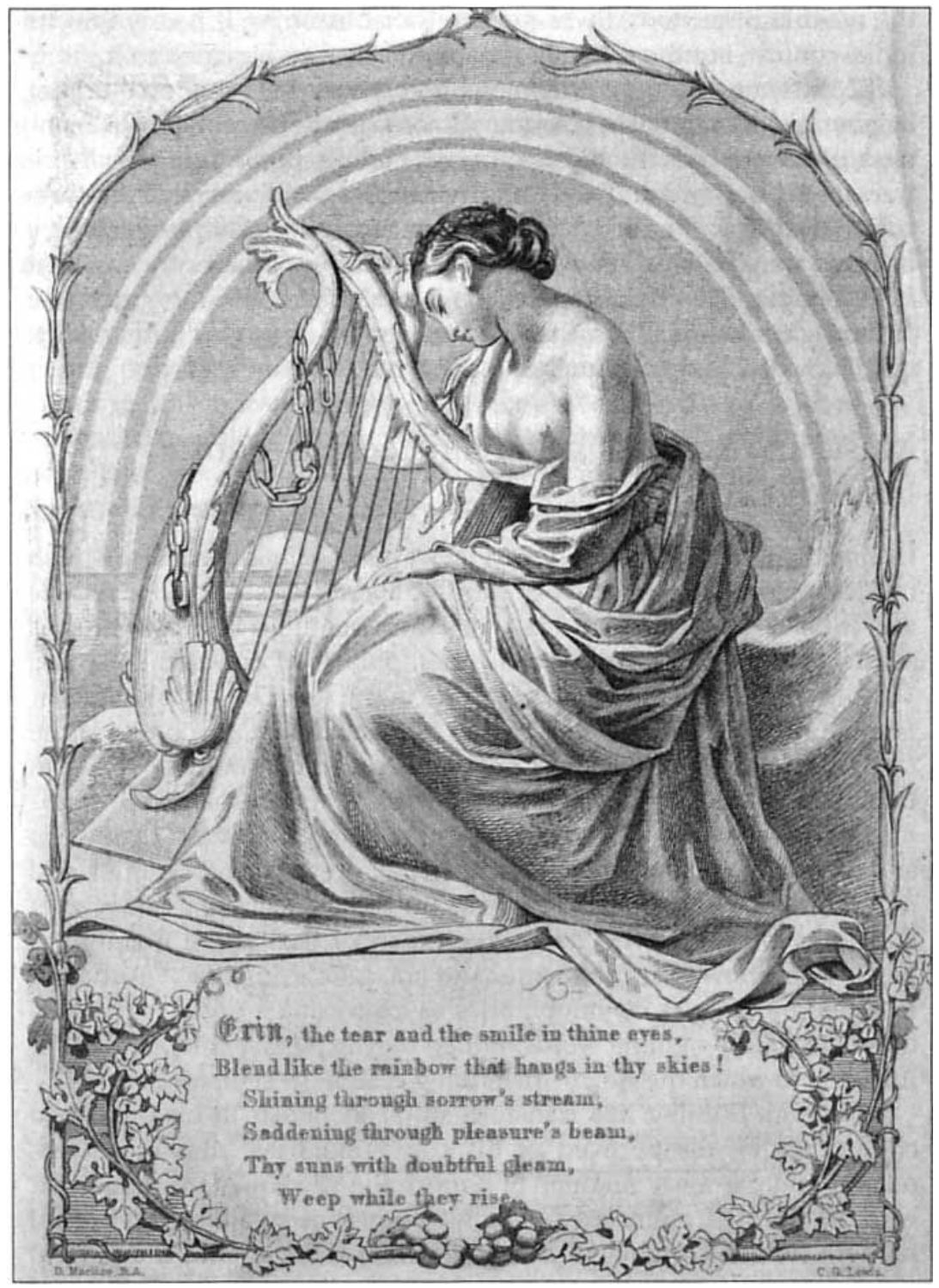

Figure 3. The languishing feminine figure representing Ireland in Daniel Maclise's illustration to Thomas Moore's song, "Erin, the Tear and the Smile in Thine Eyes", in Moore's Irish Melodies (London: Longman, Green, Longman, Roberts \& Green, 1865-89), 5. 
From the comfortable distance of the imperial centre of London, intellectuals there shared a view of the Irish that coincided with that of the cultural nationalists in Ireland. Irish culture was fashionable, especially the songs of Thomas Moore, which portrayed a sensitive, melancholy people who mourned the loss of their sovereignty. This representation of the Irish coincides with the musical stereotypes (the sentimental, melancholy Celt, the clear-headed Anglo-Saxon) assembled in the performance of the $U K$ Theme described above. They also model the colonial view of an enabling aesthetic reconciliation of opposing racial types within the British Isles-the Teuton and the Celt-that English poet and critic Matthew Arnold proposed in his influential 1866 lectures "On the Study of Celtic Literature" as potentially producing a kind of hybrid vigour which would result in a more creative English race. ${ }^{19}$ The colonial stereotype of the Irish was thus of a weaker race who possessed attractive qualities, but who needed the governance of the English colonial administration-a rationalization familiar to many colonial endeavours.

During the period when Matthew Arnold was writing and notably when there was periodic agitation from the Irish at home or in England, depictions of the Irish in newspapers and pamphlets were often quite different. Whereas the idea of an Irish people subservient to and complementing the English as part of a political union was characterized as feminine, emotional, and weak, the threat of actual Irish people who might rise up and inflict political or military harm to the union was represented by means of caricatures of the Irish as masculine, violent, and degraded.

This dichotomy had been present in colonial relations for centuries. English poet Edmund Spenser, a colonial administrator in Ireland at the end of the sixteenth century, produced in his The View of the Present State of Ireland (A Veue of the present state of Irelande [1596]) what might be regarded as a paradigm for that colonial discourse, identified by scholars in postcolonial studies, within which a colonized people is represented as disruptive and barbaric, against the colonizer, who is defined as orderly and civilized. ${ }^{20}$ Spenser's representation of the Irish as brutal and uncivilized typified the colonial view of the Irish at the time, along with a distrust of earlier Anglo-Norman colonizers whom it was feared had become politically corrupted by their assimilation of the inferior and subversive cultural practices of the native Irish and through their shared Catholic faith. ${ }^{21}$

This second stereotype of the Irish, one that co-existed with the discourse of Celticism, was utilized in the propaganda war against Irish anti-colonial movements during the nineteenth century, particularly in the English press. Its manifestations included political cartoons in which the Irish were depicted as apelike creatures. The music and dance associated with this degraded figure were far from the aristocratic harping and sweet, melancholy songs that cultural nationalists used to support their cause. Instead, the dance music that the artisan musicians of the lower classes played on fiddles and pipes and to which Irish youth danced with vigour, was depicted as wild and uninhibited.

\footnotetext{
${ }^{19}$ Matthew Arnold, “On the Study of Celtic Literature," in English Literature and Irish Politics, ed. R. H. Super (1866; Ann Arbor: University of Minnesota Press, 1973), 291-395.

${ }^{20}$ See, for example, the works of Homi Bhabha, Ashish Nandy, and Edward Said.

${ }^{21}$ See David Cairns and Shaun Richards, "What Is My Nation?', in Writing Ireland: Colonialism, Nationalism and Culture (Manchester: Manchester University Press, 1988), 1-21.
} 


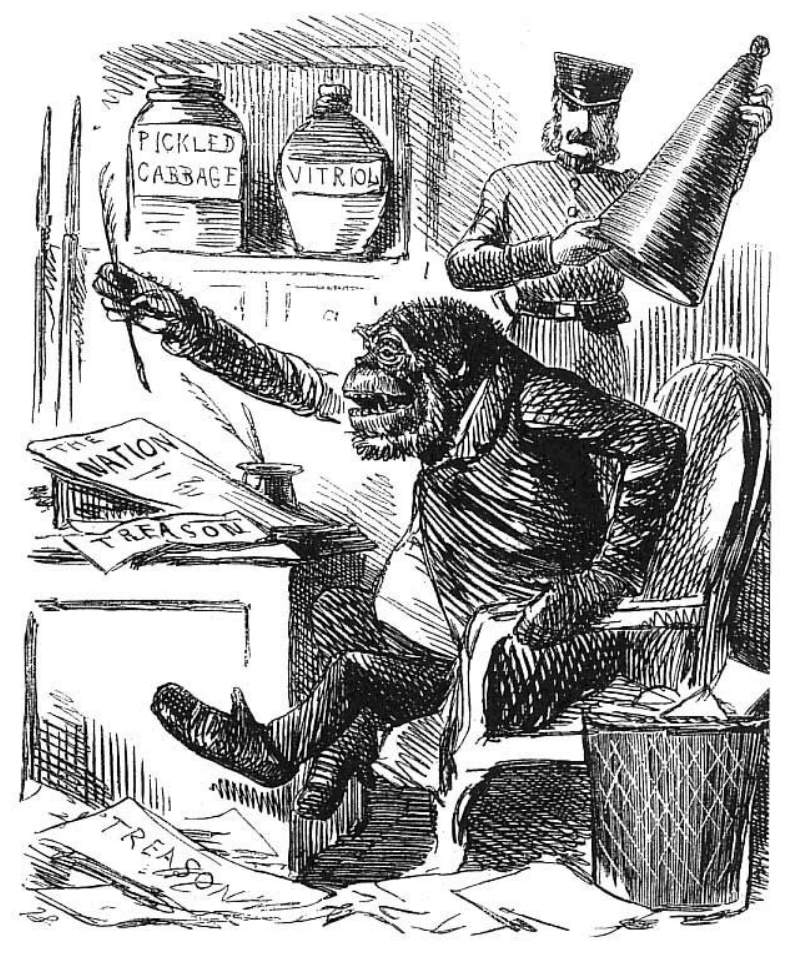

Figure 4. English cartoonist John Leech's "Mr. G-O'Rilla” appeared in Punch, 14 December 1861, accompanying an article quoting calls for Irish independence made in The Nation.

Music was an important ideological tool in both the cultural and the more militant nationalist movements in Ireland during the nineteenth century. Thomas Davis, founder of the nationalist Young Ireland movement and editor of the nationalist journal The Nation, believed that music, as " $[\mathrm{t}]$ he first faculty of the Irish," could be harnessed to empower patriotism, to "keep up their spirits, refine their tastes, warm their courage, increase their union, and renew their zeal." ${ }^{22}$ To this end, Davis wrote verses exhorting the Irish to "manly" action, setting them to the airs of popular ballads. His best known song, "A Nation Once Again," remains in the popular repertoire as a "rebel song" performed by ballad bands worldwide. This song exemplifies the way in which Davis inverted the colonial stereotype of the Irishman as a treacherous ruffian, depicting in its place the righteous patriot, who must heed the voice of God's angel, put aside "passions vain and lowly" and "make our land / A Nation once again!" This heroic figure-as against, for example, the feminine supplicant of the Aisling (discussed above)—provided a masculine model fit to reassume the role of national leadership and military action.

Numerous scholars have contributed studies of constructions of gender in Irish colonial and nationalist discourses. ${ }^{23}$ These trace symbolic representations of Ireland following Ireland's invasion by

\footnotetext{
${ }^{22}$ Thomas Davis, cited in Francis O’Neill, The Dance Music of Ireland: 1001 Gems (Dublin: Waltons, 1965 [1907]), 3.

${ }^{23}$ See, for example, Ann Rosalind Jones and Peter Stallybrass, "Dismantling Irena: The Sexualising of Ireland in Early Modern England," in Nationalisms and Sexualities, ed. Andrew Parker et al. (New York and London: Routledge, Chapman \& Hall), 157-71; David Lloyd, Anomalous States: Irish Writing and the Post-Colonial Moment (Dublin: Lilliput, 1993); Maurice Goldring, Pleasant the Scholar's Life: Irish Intellectuals and the Construction of the Nation State (London: Serif, 1993); Richard Kearney, Postnationalist Ireland: Politics, Culture, Philosophy (London and New York: Routledge, 1997); Helen O'Shea, “'Good Man, Mary!': Women Musicians and the Fraternity of Irish Traditional Music," Fournal of Gender Studies 17, no. 1 (March
} 
England, first as the vulnerable virgin raped by the masculine invader, and later, with the rise of nationalism, as a mother to be defended and protected from colonial domination. Nationalists in Ireland, as in most European nationalist movements (Germany is an exception) embrace the concept of the motherland, in which the putative nation is personified as feminine, a fluid figure who in different situations might be represented as a maid in need of masculine protection (as in subversive resistance movements against colonial invasion), as a woman warrior (in military anti-colonial movements), or as a protective mother (once a nation has won independence). In the first of these tropes, the threatened woman represents simultaneously the national territory and its people; in the second, the figure of the woman warrior represents all the people of the nation, imputing their unity of purpose; in the third, the trope of mother is the nurturing nation-state, whom citizens should obey out of filial love. A fourth feminine trope became a part of the symbolic language of Irish nationhood (although, again, this concept is not confined to Ireland) in the figure of Irish womanhood: the mother whose place is in the home supporting her man and nurturing the next generation of citizens.

The ideal woman of the new nation, a version of the mythical Mother Ireland, is enshrined in Ireland's 1937 Constitution, which narrowly delineates the possibilities for women in Irish society:

Article 41, 2.1: In particular, the state recognises that by her life within the home, woman gives to the state a support without which the common good cannot be achieved.

2.2: The state shall, therefore, endeavour to ensure that mothers shall not be obliged by economic necessity to engage in labour to the neglect of their duties in the home. ${ }^{24}$

As Elizabeth Butler Cullingford argues, such representations have a continuing power to constrain Irish people in general and Irish women in particular: "as applied by Irish men it has helped to confine Irish women in a straitjacket of purity and passivity; as applied by English cultural imperialists it has imprisoned the whole Irish race in a debilitating stereotype. ${ }^{25}$ For example, feminist historians have noted that, while women were active participants in the early years of that anti-colonial struggle, once an independent state was formed, they became increasingly excluded from political life, as their participation was contained in separate "women's auxiliaries." The same holds true for the socialists who supported the anti-colonial movement and were sidelined by the new state. ${ }^{26}$

An analogous situation occurred in musical life after independence. The dance tunes that by this time were regarded as "national" and also "ancient"-although in most cases they were neither, having largely Scottish and some English provenance-increased in symbolic status from association with wildness and intemperance with the rise of the Gaelic League, a new development in cultural nationalism which focused on the preservation and use of the Irish language as well as Irish music and dance. The Gaelic League promoted their own repertoire of what they considered the true "national" dances, which were versions of old long and circle dances that had been substantially adapted for the ballroom. These became the "official" Irish dances and the Gaelic League sought to have the more popular quadrille "sets" banned because they derived from "foreign" dances.

2008): 55-70; and Colin Graham, “Subalternity and Gender: Problems of Post-colonial Irishness,” Gender Studies 5, no. 3 (1996): 363-73.

${ }^{24}$ Republic of Ireland, Constitution of 1937, cited in J. J. Lee, Ireland 1912-1985: Politics and Society, (Cambridge, UK; New York: Cambridge University Press, 1989), 150.

${ }^{25}$ Elizabeth Butler Cullingford, “Thinking of Her . . as . . Ireland': Yeats, Pearse and Heaney,” Textual Practice 4, no. 1 (1990), 1-21.

${ }^{26}$ See in particular Caitríona Beaumont, "Gender, Citizenship and the State in Ireland, 1922-1990," in Ireland in Proximity:

History, Gender, Space, ed. Scott Brewster et al. (London and New York, Routledge, 1999), 94-108. 
During the 1930s, these "céili dances," as the Gaelic League's approved dance repertoire came to be called, ${ }^{27}$ began to spread more widely through Ireland, partly as a result of the banning of unlicensed dances held in private houses (at that time a common rural social practice), and the suppression of jazz and jazz dancing. Instead, Irish citizens were encouraged to dance the relatively chaste céili dances in new parochial halls built for public dancing under the watchful eye of the parish priest. By the end of the 1930s this transformation was complete, with most social dancing in rural areas consisting of the performance of revived Irish line and circle dances with some ballroom dances such as the waltz and the barn dance.

Music that promoted a feminine delineation of Ireland-for example, the many sentimental songs set to the "Londonderry Air"-flourished in the drawing room and the parlour. The stereotype of the Irish as artistic, weak and unreliable (thus, according to the understanding of the times, "feminine") did not undergo a similar inversion at the hands of the cultural nationalists. This was in part because, as a largely urban movement of the intelligentsia, who were predominantly Anglo-Irish, cultural nationalists were at arms length from the hoi polloi, regarding themselves as their "natural" leaders. Celticism's version of the Irish as sentimental and melancholy survives into the twenty-first century in art-music performances of music emblematic of Ireland (including elaborate settings of the "Londonderry Air" performed in bel canto style). After the establishment of the Irish Free State in 1922, the "classical" harp repertoire was discredited through its association with the former Protestant Anglo-Irish ruling class in Ireland and was relegated to urban, high-culture performance almost exclusively by women (on modern instruments such as the concert harp—as Mary O'Hara used, for example — not the reproductions of eighteenth-century harps often used today).

The transformation in musical practice considered emblematic of Ireland, from the feminine delineation of "classical" Irish music revived by cultural nationalists to the masculine delineation of dance music played by dance bands, was clinched by the formation of dance bands to play in the new parochial halls. Several concurrent changes moved public performance of Irish dance music (by this time called "traditional" music) more decisively from a feminine to a masculine delineation. The first was in the move from private domestic contexts to the public space of the dance hall mentioned above. The second was in the makeup of the céili bands that played in these halls, which were almost exclusively male, women players being accepted on the basis of playing the piano (in rural Ireland, largely the province of women) and with a chaperone such as a male relative or a member of the clergy. Thirdly, the larger space of the dance hall required that more sound be produced and this not only necessitated a band rather than one or two individual musicians (this was before public address systems—and electricity-in rural areas) but also louder instruments. The chromatic button accordion as it has been used in Irish music would seem to support musicologist Lucy Green's proposition that women are discouraged from playing the 'biggest, loudest and most technologically advanced instruments'. ${ }^{28}$ In its earlier and simpler form of the melodeon it was considered a "poor-person's instrument" and one well suited to children and women because of its simplicity. By the 1930s, the larger, louder, and more complex chromatic button accordions- "as impressive as their power is commanding"-were widely used in Ireland and the instrument became

\footnotetext{
${ }^{27}$ The term "céili" is a borrowing from the Scottish cultural nationalist movement, as is the project of creating a national dance form based on "ancient" dances but adapted to the ballroom. This cross-fertilization took place in London, where cultural nationalists from Ireland and from Scotland were active in the last decades of the nineteenth century.

${ }^{28}$ Lucy Green, Music, Gender, Education (Cambridge: Cambridge University Press, 1997), 58.
} 
indispensable in the céili band line-up, capable of carrying the music to the farthest corners of a hall. ${ }^{29}$ It was played almost exclusively by men until the 1980s.

These mid-twentieth-century changes in the performance of Irish traditional music set the stage for the revival that began in the 1950s. Migrant labourers who had worked on post-war reconstruction projects in England began to return to Ireland during this period, bringing with them a new context for playing Irish traditional music: the pub session. Women were absent from this scene in an even more pronounced way than in the céili bands that were in their prime in the 1940s. Not only did the "masculine" button accordion dominate these gatherings, but the pub itself was unavailable to women, to an even greater degree than was the dance-hall stage, because even as listeners, women were not welcomed in public bars. As feminist geographer Doreen Massey writes, public space is constructed as masculine and "home" as woman's place, and these symbolic meanings both reflect the ways in which gender is understood and further constrain women and men from participating with equality in both public and private spheres. ${ }^{30}$ If a public space such as the dance hall may be regarded as a masculine domain, in contrast to the feminine domestic realm, then the pub, as a masculine refuge from the constraints of female presence and values, was hyper-masculine. Even in twenty-first century Ireland, women and men are subject to very different standards of behaviour and etiquette in the pub (for example, in the degree of acceptance of drunkenness).

By the beginning of the revival movement of Irish traditional music in urban centres in Ireland and England in the 1950s, Irish dance music was predominantly a masculine musical practice that also carried masculine symbolic meanings. Changes that took place in Irish musical practice during the first half of the twentieth century, as discussed above, saw women's place in Irish traditional music move from a role in which they might play music for dancing and listening within the domestic domain and to a mixed audience of friends and relations, to a situation in which it was rare for a woman to be accepted as a musician playing for dancing (in a public hall) or for listening (in a pub session). It has really only been since the 1970s that women's participation in Irish traditional music has gradually moved back into the public domain and women have taken up the louder and more "masculine" instruments such as the accordion and the banjo. On other instruments with a strong masculine association (the villeann pipes and the bodhran or frame drum), and other accompanying instruments (such as the guitar), performers are almost always men.

Today girls and women predominate as learners of Irish traditional music, attending classes and summer schools in far greater numbers than boys and men. It has been observed, however, that prizewinners in national music competitions are much more likely to be male. ${ }^{31}$ This differential becomes more obvious the higher the status of the musical activity: recording artists, festival performers, composers, commentators, critics, music organization presidents, summer school organizers, radio and record company producers, and so on. In performing and recording groups, women overwhelmingly continue in the conventionally feminine roles of singer and keyboard player. ${ }^{32}$

\footnotetext{
${ }^{29}$ Sean Quinn, “Accordion,” in The Companion to Irish Traditional Music, ed. F. Vallely (Cork: Cork University Press, 1999), 23.

${ }^{30}$ Doreen Massey, Space, Place, and Gender (Minneapolis: University of Minnesota Press, 1994). See also Gillian Rose, Feminism and Geography (Cambridge: Polity Press, 1993).

${ }^{31}$ Rina Schiller, "Gender," in Vallely, The Companion to Irish Traditional Music, 150-51.

32 See Green, 59.
} 


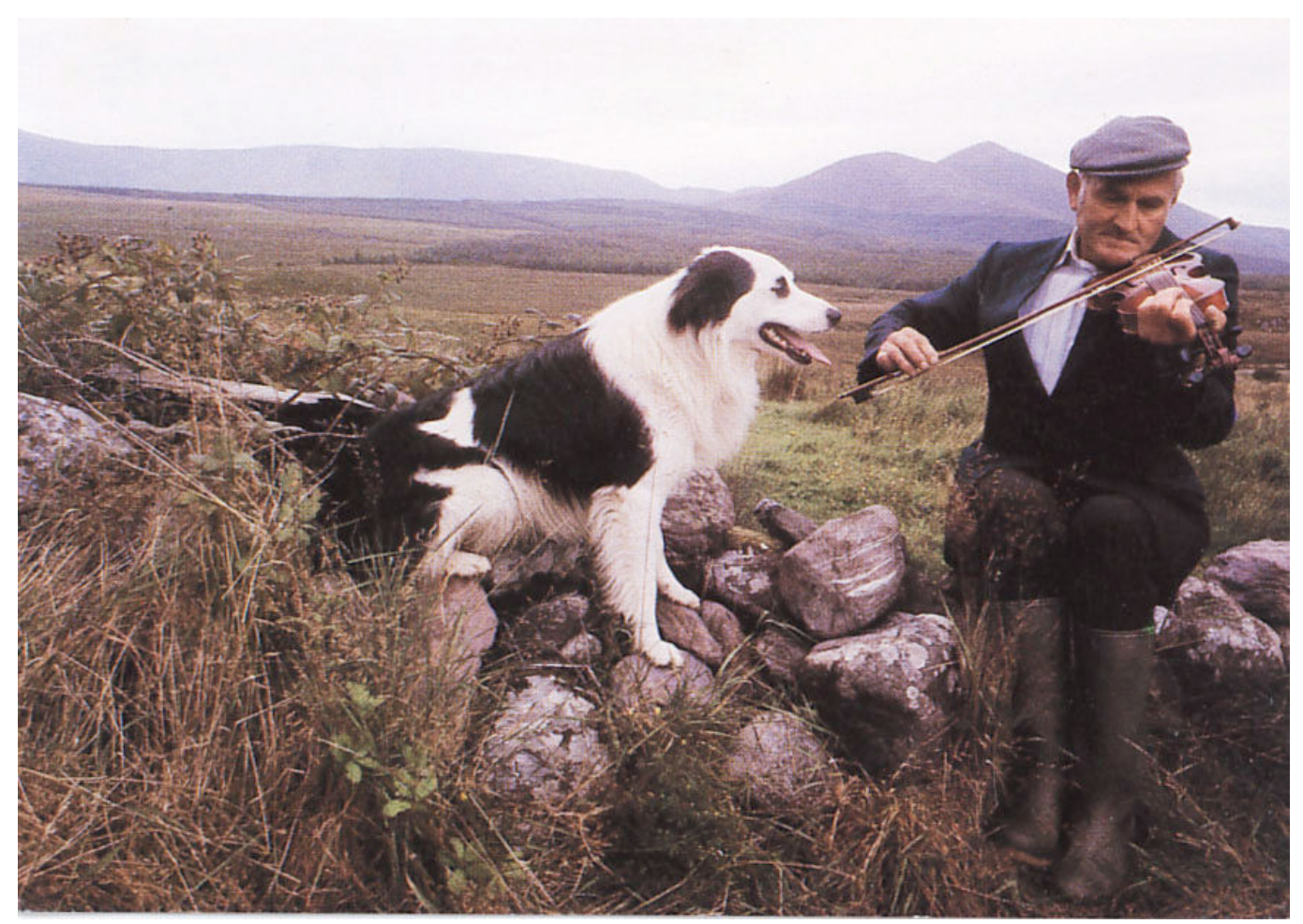

Figure 5: In popular representations, the generic Irish traditional musician is a masculine figure, of mature age and from a rural background. Postcard published by Cardall Ltd, Dun Laoghaire, Co. Dublin, n.d.

As I have argued elsewhere, ${ }^{33}$ women's participation in these informal sessions of Irish traditional music has been constrained by societal values that accord men higher status in mixed gatherings; that conventions governing the conduct of these gatherings, particularly the status and authority given to those who are oldest and most renowned. For various reasons, women are unlikely to be either of these. While women's participation in public music sessions has increased exponentially since the 1970s, as with the introduction of women into other previously forbidden realms of public life (universities and polling booths, for example), it takes some time before men and women fully internalize women's entitlement to be in such places and to have an equal status there.

\section{Conclusion}

Edward Said alerts his readers to the worldliness of musical texts, in which the social and political circumstances of their creation, dissemination, and reception are always implicated in the meanings we take from them. As I have argued above, this contingency of meaning, its situatedness in and particularity to political time and place, is manifest as much in our understanding of one particular melody as it is in our understanding of musical instruments, musicians, and nations.

The construction of a body of musical practice understood to represent and express the Irish condition has taken place within the discourse of nationalism. Perhaps the most important aspect of this is

\footnotetext{
${ }^{33}$ See O’Shea, “'Good Man, Mary!””
} 
the emphasis on a single, united cultural identity. Despite the many geographical, religious, class, economic, and political differences among Ireland's citizenry, in terms of their identity they are considered "the same." This "sameness" has been transformed, during the process of Ireland's move from an English colony to an independent nation-state, from a feminine to a masculine delineation through the replacement of a colonial view of the Irish as incapable of self-rule by one in which the masculine patriot carries the authority to perform the national cultural identity.

Irish traditional music was accorded a feminine symbolic identity by cultural nationalist movements in Ireland from the late eighteenth century. Music like the air we know best as "Danny Boy" became associated with instruments constructed discursively as feminine (the harp and the piano) and with a stereotype of Irishness that was held to be weak and emotional (and thus, according to contemporary values, "naturally" feminine).

This feminine stereotype was put under pressure as more militant anti-colonial movements rejected the adequacy of the cultural nationalist project and sought an independent state for Ireland. That transformation involved the adoption of a more masculine image. The symbols adopted, including musical symbols, were more militaristic and involved marching bands (still marching in many villages and towns in rural Ireland) and instruments with masculine associations, such as pipes and drums, as well as the musicians themselves being men. Women musicians disrupt the performance of this Irish identity because the symbolic language of nationalism represents the Irish patriot and Irish traditional music as masculine.

Both the representation of the ideal Irish woman as confined to domestic life, and the redefinition of Irish music as a masculine domain in which male musicians are the "natural" leaders, resulted in limited opportunities for women to perform Irish traditional music publicly, particularly in the early decades of the independent Irish state, from the 1920s to the 1950s. While societal values continue to accord men higher status in mixed gatherings, and public performance is located mainly in the masculine territory of the pub, the lesser participation of women as musicians has also reinforced their lack of authority across the years, as critics and commentators, as composers and producers. In such ways, both the ideology of the nation and the social values that sustain it weave a constantly mutating web of worldliness around the production and consumption of musical texts.

\footnotetext{
Abstract

This article examines some of the ways in which defining a set of musical practices as "national" reproduces both the stereotypes adopted by colonizers and inverted in anti-colonial movements, and also the exclusions that are integral to the processes of nation formation. As one of the cultural forms nationalists enlist in their project, music is regarded by them as reflecting the imagined political, territorial, and cultural unity of the putative nation's people. I use the case of Irish traditional music, and the exemplar of the song "Danny Boy," first to demonstrate that the meanings attributed to musical texts are contingent upon the social and political circumstances of their production and consumption, and then to argue that the ideal Irish musician is discursively constructed as masculine.
} 